\title{
TITLE:
}

\section{$<$ Note> New Nut-Cracking Sites in Diecké Forest, Guinea: An Overview of the Surveys}

\section{$\operatorname{AUTHOR}(S)$ :}

Carvalho, Susana; Sousa, Cláudia; Matsuzawa, Tetsuro

\section{CITATION:}

Carvalho, Susana ...[et al]. < Note> New Nut-Cracking Sites in Diecké Forest, Guinea: An Overview of the Surveys. Pan Africa News 2007, 14(1): 11-13

ISSUE DATE:

2007-06

URL:

http://hdl.handle.net/2433/143472

RIGHT:

Copyright (c) Pan Africa News. 


\section{$<$ NOTE $>$ \\ New Nut-Cracking Sites in Diecké Forest, Guinea: An Overview of the Surveys}

\author{
Susana Carvalho ${ }^{1}$, Cláudia Sousa ${ }^{2}$, \\ Tetsuro Matsuzawa ${ }^{3}$ \\ 1. Dpt. Anthropology, Faculty of Sciences and Technology, \\ University of Coimbra, Portugal \\ 2. Dpt. Anthropology, Faculty of Social and Human Sciences, New \\ University of Lisbon, Portugal \\ 3. Primate Research Institute, Kyoto University, Japan
}

\section{INTRODUCTION}

We report the results of the 2006 KUPRI (Kyoto University Primate Research Institute) surveys in Diecké forest, Guinea, Western Africa.

Research in the Diecké forest by KUPRI started in 1999 with a preliminary survey ${ }^{1}$. This continued in 2000, with the survey of Nonah and Yossono areas ${ }^{2}$. The main objective was to find a good research site that would allow for comparative studies between different communities of wild chimpanzees. It has been acknowledged, since the first field season, that Diecké chimpanzees crack open nuts (Panda oleosa and Coula edulis) using stone and root anvils and stone hammers. Nut-cracking behaviour had not been observed directly until today and there are very few reports on chimpanzee's direct observation $^{2,3}$.

The Diecké forest is part of the Guinean Forests and integrates the region comprised by lowland forests, being one important world spot for the biodiversity. These forests survived after the retraction and division of Pleistocene forests, partly due to the ice age that dried the climate cyclically ${ }^{4}$.

This forest, Fôret Classée de Diecké, is a protected area of $600 \mathrm{~km}^{2}$, located in the South-eastern part of Guinea, $50 \mathrm{~km}$ west from Bossou, bordering Liberia on the south. The reserve is controlled by the Centre Forestier de N'zerekoré, and Diecké biodiversity is managed by a German project located at the Direction Generale de Centres Forestiers, also in N'zerekoré. This project, entitled PROGERFOR, focuses on conservation/ reforestation; damage minimization; regional development, and organized the forest in thirty parcels with three levels of protection.

Diecké is characterized by a large number of small hills, averaging $350 \mathrm{~m}$ of altitude (the highest point being Mont Jna, with $800 \mathrm{~m}$ ). Two main rivers cross the forest running south: Nyé on the west side, and Gbin, divided in Gbin and Gbin-bé, on the east side. Secondary waterlines are abundant in the forest creating swamps. In this part of the country, the dry season is very short, from December or January to March or April.

Geologically, Diecké is part of the West African craton with Precambrian rocks, essentially igneous and

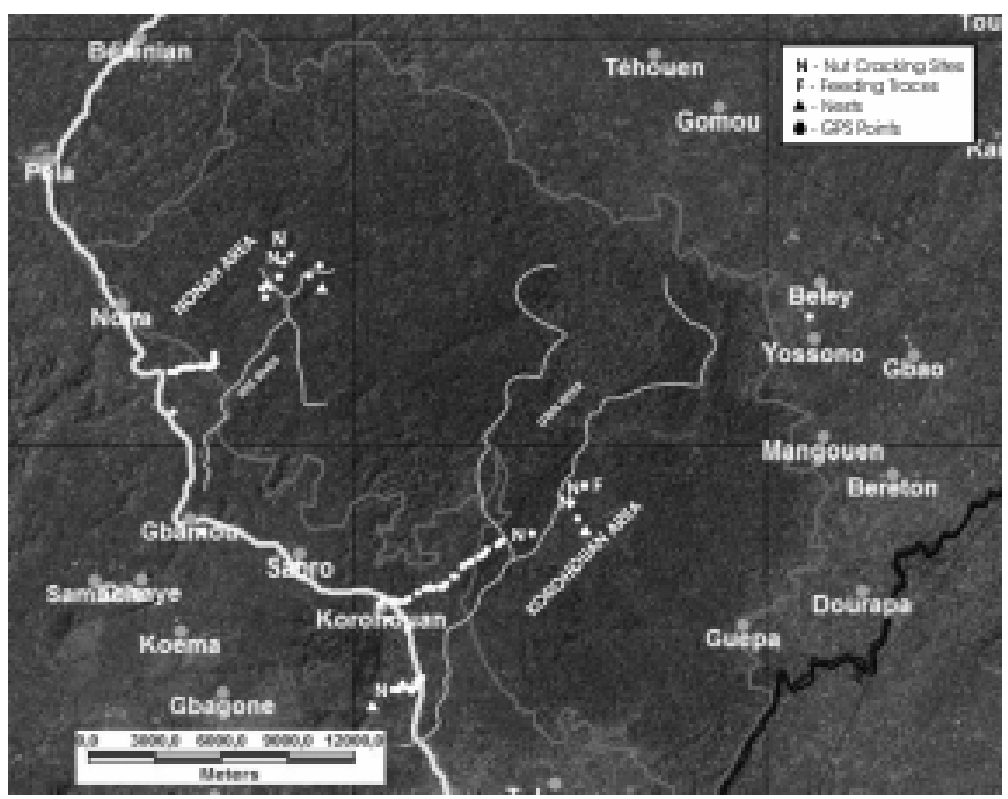

Fig. 1. One of the satellite views of Diecké Forest covering the surveyed areas in Nonah area and Korohouan area (Credits: S. Carvalho / PRI-Kyoto, 2006). 
metamorphic ${ }^{5}$. Concerning raw material availability in the primary forest zone, i.e. stone types and nut species, enormous granite outcrops were observed and movable quartz stones were found near waterlines.

Nut species of Panda oleosa tree and Coula edulis tree are inside the integral protected area (per. obs.), as these are species from mature forests ${ }^{6}$. Elaies guineensis is not present in the primary forest; however it is possible to locate natural, or human planted, Elaeis in the peripheral area.

\section{The etho-archaeological surveys}

In 2006, chimpanzee research continued in this area, combining primatological and archaeological methods, while new zones were surveyed. The KUPRI work team, accompanied by local guides, carried out three survey incursions between January and April 2006 and set two temporary camps in the core of the forest, one departing from Nonah village ( $7^{\circ} 31^{`} 50.9^{\prime \prime} \mathrm{N}$; $\left.9^{\circ} 04{ }^{\prime} 27.7^{\prime \prime} \mathrm{W}\right)$ and another from Korohouan village $\left(7^{\circ} 26^{\wedge} 09.6^{\prime \prime} \mathrm{N} ; 8^{\circ}\right.$ 59`22.2`W) (Fig. 1).

A selected survey was performed searching for nut trees. Once it was apparent that nut-cracking places were located near water lines, the survey was directed to these points. When one nut-cracking site was found, a radio centric survey was attempted, $1 \mathrm{~km}$ around the nut-cracking area. As a result, six nut-cracking sites were recorded, four of them previously unknown.

A pilot survey was carried out in January, for three days, departing from Nonah village. The aim was to collect information and to prepare local work teams to enter the forest. During this survey, a nut-cracking site of Panda oleosa nuts was detected (SB1) (Table 1). Originally discovered by Matsuzawa ${ }^{1}$, SB1 is located around a three

hours walking distance from Nonah to NNE direction. Here it was recorded a total of seventeen tools: eleven hammers and six outcropping anvils.

In March another survey was undertaken over an eight day period. The SB1 place had been visited by chimpanzees, allowing the recording of tool use. The base camp was set to Northeast from SB1, crossing Lilaya watercourse.

During this trip another nut-cracking place (SB2) of Panda oleosa nuts, was identified, located east of SB1. Seven tools were recorded: four hammers and three outcropping anvils. Raw materials were, preferentially, granite and quartz (Table 1).

Survey continued in an easterly direction, passing the Nyé River (Fig.1), four hours walking from the base camp. In this area, mature fruits of Monkey orange or Elephant orange tree (Strychnos spinosa) were observed, as well as Parinari excelsa fruits.

During another survey, the Kolpégue watercourse ( $7^{\circ}$ $34{ }^{`} 31,4^{\prime \prime} \mathrm{N}$; $\left.9^{\circ} 01^{`} 43,1^{\prime \prime} \mathrm{W}\right)$ was crossed to arrive at the Taffa river area $\left(7^{\circ} 34^{`} 26,5^{\prime \prime} \mathrm{N} ; 9^{\circ} 00^{`} 49,4^{\prime \prime} \mathrm{W}\right)$, five hours walking from the base camp. In Taffa area one chimpanzee sleeping trace was recorded-an old bed.

In April, one survey was carried out over a period of seven days. The goal was to survey the Korohouan area. Moving east, we crossed the Gole watercourse $\left(7^{\circ} 26^{`} 18\right.$, $8^{\prime \prime} \mathrm{N}$; $\left.8^{\circ} 58^{`} 41,3^{\prime \prime} \mathrm{W}\right)$, Melu watercourse (7² $27^{`} 03,5^{\prime \prime} \mathrm{N}$; $\left.8^{\circ} 57^{`} 20,8^{\prime \prime} \mathrm{W}\right)$, Gbin river $\left(7^{\circ} 27^{`} 08,3^{\prime \prime} \mathrm{N} ; 8^{\circ} 57^{`} 12\right.$, 5 'W), Dené watercourse and Sakai watercourse. On the right border of Sakai watercourse, a new nut-cracking site (SB 3) of Panda oleosa, was found (Table 1). This site was abandoned some years before and showed a large archaeological assemblage. Visible hammers were often fractured and site characteristics were similar to SB1 and

Table 1. Location of the six nut-cracking sites recorded during 2006 field season in Diecké forest. The grey colour indicates the new sites.

\begin{tabular}{|c|c|c|c|c|c|c|c|c|}
\hline Date & sine & $\begin{array}{l}\text { Survey } \\
\text { Acea }\end{array}$ & Latitude N & Lengitude W & Alt, $m$ & Nut sp. & $\begin{array}{l}\text { Wader } \\
\text { Pron. }\end{array}$ & $\begin{array}{l}\text { Fruit tree } \\
\text { Prook. }\end{array}$ \\
\hline 220106 & 581 & Niazh & 07.33'574 & ocoraz'o7. $i^{-1}$ & 424 & Mande whaner & Yes & Yes \\
\hline 11.03 .06 & 582 & Neath & $6 \times 3954.1$ & coovez oL & 366 & Masde whins & Yis & Yes \\
\hline 166405 & 589 & Kerobian & $6725^{2} 537^{11}$ & $966^{2} 55^{\prime} \Delta 15^{\prime \prime}$ & 317 & Munderthos & Ves & Yos \\
\hline 17.0406 & SB4 & Kofolians & 0724048" & 06854232 & 356 & Cindiedter & Vis & Yes \\
\hline 17.0405 & SBS & Kotulanes & 6r:2404 & $0655422.4^{\circ}$ & 377 & Cientionter & Ves & Yes \\
\hline 100406 & $\operatorname{ses}$ & $\begin{array}{l}\text { Korolinese } \\
\text { AMas Medial }\end{array}$ & oratoss & ocessisso & 394 & Mashe whens & Yex & Yin \\
\hline
\end{tabular}

SB2. A total of forty tools were recorded: one hammer, eight outcropping anvils, and thirty-one fragments of hammers.

The base camp was set on the left border of Gbin-bé river $\left(7^{\circ}\right.$ $\left.28^{\prime} 14,6^{\prime \prime} \mathrm{N} ; 8^{\circ} 54^{` 3} 3,6^{\prime \prime} \mathrm{W}\right)$. Fresh traces of chimpanzee feeding of 
Landolphya owarensis were observed in the base camp area.

Following to NNE, two new nut-cracking sites of Coula edulis were found (SB4, SB5) (Table 1). These sites had been used about one month before. In SB4 a total of six tools were recorded: three hammers and three outcropping anvils. In SB5 eleven tools were detected: eight hammers and three outcropping anvils. It was also observed that plenty of Cola cordifolia fruits had been eaten in this area.

The last survey departed from Korohouan to the Southwest, outside the Diecké protected area. The Mont Medou area - a remaining fragment

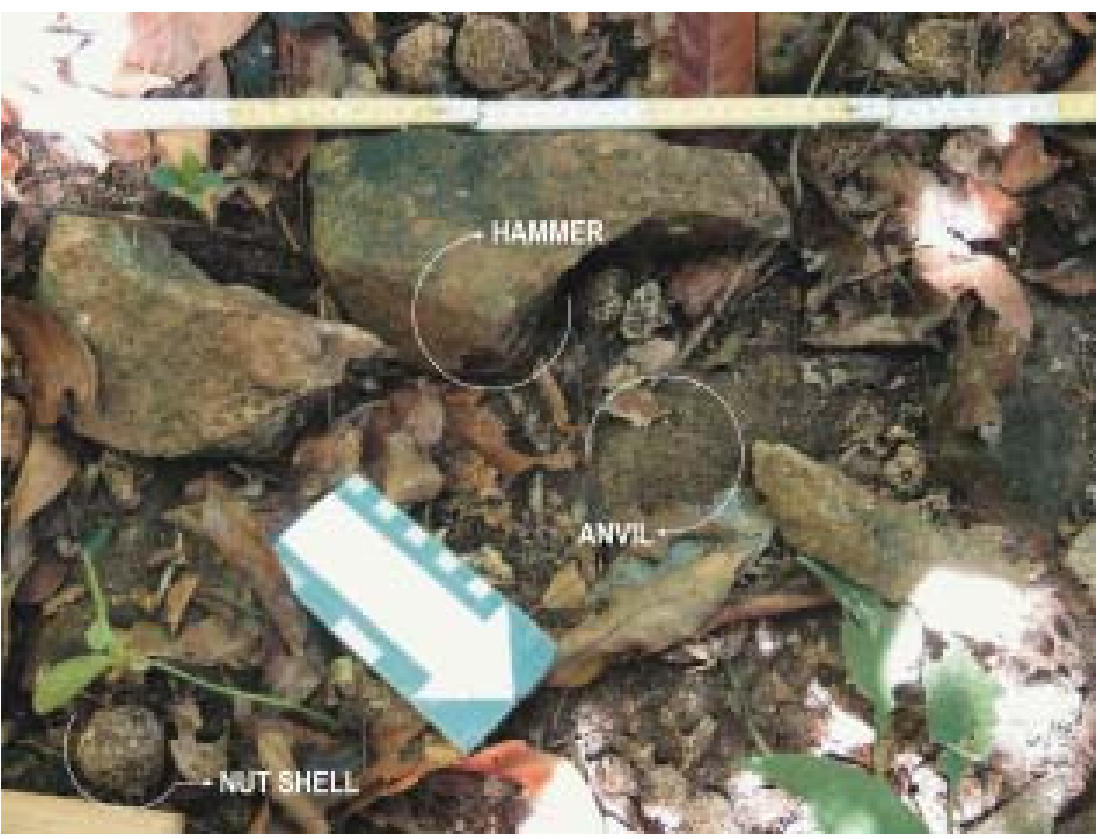

Fig. 2. The SB 6 site in the Kourouhan area (Mont Medou). Large quartz hammers to open crack the Panda nuts were found on the top of the outcropping anvil. Refitting of stones was also detected. of primary forest - was surveyed. A

new nut-cracking place (SB6) of Panda oleosa nuts was found on the right margin of the Kpayan River (Table 1). Here, a total of ten tools were recorded: six hammers and four anvils. Two hammers were fractured in several pieces (Fig. 2). Following the Kpayan River we reached the top of a valley where 25 beds were $\left(7^{\circ} 24^{\prime} 07,2^{\prime \prime} \mathrm{N} ; 8^{\circ} 59^{`} 03\right.$, 4'W).

Chimpanzee feeding, sleeping and travel traces were found in the core and periphery areas of Diecké forest; the latter provided banana plantations and other agricultural fields as alternative food resources. Future surveys will determine the size and the home range of the possible different groups. We further expect to continue the symbiotic approach between archaeology and primatology in order to understand some of the older chimpanzee nut-cracking sites regarding technological and typological variance among chimpanzee groups.

Acknowledgments. We thank the Direction National de la Recherche Scientifique et Technique, République de Guinée, and Dr. Kourouma Makan, Director of the Institut de Recherche Environnemental de Bossou for permission to conduct field work at Diecké. We also thank Dr. Werner Grimmelman and Progerfor. The research was supported by Grants-in-Aid for scientific research from the Ministry of Education, Science, Sports, and
Culture of Japan: MEXT-16002001, JSPS-HOPE, JSPS-21COE-Kyoto-Biodiversity, and Global Environment Research Fund (F-061 to T. Nishida) of the Ministry of Environment, Japan. We thank B. Zogbila, H. Gbelegbe, G. Doré, P. Goumy, J. M. Kolié, J. Malamu, L. Tokpa, A. Kbokmo, C. Koti, O. Mamy, for the field support. We are grateful to Francisco Almeida for comments on the manuscript.

\section{REFERENCES}

1. Matsuzawa T, Takemoto H, Hayakawa S, Shimada M 1999. Diecké Forest in Guinea. Pan Afr News 6: 10-11.

2. Humle T, Matsuzawa T 2001. Behavioural diversity among the wild chimpanzee populations of Bossou and neighbouring areas, Guinea and Cote d'Ivoire, West Africa: A preliminary report. Folia Primatol 72(2):57-68.

3. Kormos R, Humle T, Brugière D, Fleury-Brugière M, Matsuzawa T, Sugiyama S, Carter J, Diallo MS, Sagno C, Tounkara EO 2003. The Republic of Guinea In: Status Survey and Conservation Action Plan West African Chimpanzees, Kormos, R, Boesch C, Bakarr MI, Butynski TM (eds), IUCN/SSC Primate Specialist Group. Published by IUCN, Gland, Switzerland and Cambridge. UK.

4. Caldecott J, Kapos V 2005. Great ape habitats: tropical moist forests of the old world. In: World atlas of great apes and their conservation, Caldecott J, Miles L (eds), California: University of California Press.

5. Clark JD 1967. The atlas of african prehistory. Chicago \& London: The University of Chicago Press.

6. White L, Abernethy K 1996. Guide de la vegetation de la reserve de la Lopé. Écofac Gabon. Multipress Gabon. Gabon. 